Mirjana Knezevic ${ }^{1}$

ORIGINAL SCIENTIFIC ARTICLE

Srdjan Sapic ${ }^{2}$ doi:10.5937/ekonomika1803001K

University of Kragujevac, Received: March, 15, 2018

Faculty of economics Accepted: May, 20, 2018

\title{
LEGAL REGULATION AND USAGE OF ELECTRONIC TRADE IN REPUBLIC OF SERBIA
}

\begin{abstract}
The topic of the research is examination of the extent to which legal regulative impacts over the level of usage of electronic trade in Republic of Serbia. The main goal of this paper is to determine the impact of legal regulation through safety and privacy over the level of use of electronic trade, as well as identifying areas which should be improved and advanced in order to increase usage of electronic trade in Republic of Serbia.

Authors strive to indicate the importance of further research of the area of electronic trade in order to induce creation of adequate legal regulation above all for contracts signed via electronic signature, where expected results should contribute not only to development of electronic trade and balancing of regulatory framework with countries of European Union, as well as other scientific disciplines in researches which are directly and indirectly related to this matter.

In this paper for the need of arrangement and grouping the data is also used statistical method. All gathered data were processed in statistical software "SPSS". The result of the research demonstrated that there was positive impact of legal regulative over safety and privacy in use of electronic trade, as well as positive impact of safety and privacy on intensity of electronic trade's use.
\end{abstract}

Key words: electronic trade, legal regulative, safety of e-trade, privacy, usage of electronic trade

Jel classification: E69, G18, K22,

\section{ПРАВНА РЕГУЛАТИВА И КОРИШЋЕЊЕ ЕЛЕКТРОНСКЕ ТРГОВИНЕ У РЕПУБЛИЦИ СРБИЈИ}

\section{Апстракт}

Предмет овог рада је испитивање у којој мери и на који начин правна регулатива утиче на ниво коришћења електронске трговине у Републици Србији. Основни ичиљ овог рада је утврдити утицај правне регулативе преко безбедности и приватности на ниво корисћена електронске трговине као и уочавање подручја која је неопхоно унапредити и побољшати ради повећања коришћења електронске трговине у Републиичи Србији.

Аутори настоје да укажу на значај даљег истраживања области електронске трговине ради поспешивањ а стварања адекватне правне регулативе пре свега за уговоре закључене електронским путем, при чему очекива-

\footnotetext{
${ }^{1}$ mknezevic@kg.ac.rs

${ }^{2}$ ssapic@kg.ac.rs
} 
ни резултати треба да допринесу не само развоју електронске трговине и усклађиваюу регулаторног оквира са земљама Европске уније, већ и другим научним дисциплинама које се директно или индиректно баве овом материјом.

У раду је за потребе сређивања и груписања података коришћена и статистичка метода. Сви прикупљени подаџи су обрађени у статистичком софтверу „СПСС“. Истраживање показује да постоји позитиван статистички позитиван утицај правне регулативе на ставове о безбедности и приватности коришћења електронске трговине, као и позитиван статистички значајан утицај приватности на интезитет коришћења електронске трговине.

Кључне речи: Е-регулатива, Е-трговина, безбедност е-трговине, приватност, коришћење електронске трговине.

\section{Introduction}

The needs of economic entities for information and communication technology, in modern conditions of doing business and electronic trade based upon this, are more and more accentuated. Electronic trade becomes more and more imperative of world market competitiveness.

Development of electronic trade was initiated during $70 \mathrm{~s}$, as the result of development of global economy and global computer network (40). Creation of totally new, global, electronic trade based upon information, economic and legal entities as its participants, through electronic trade achieve faster and easier financial transactions, easier operations and more efficient realization of business. It is created business environment where all business processes have the goal to be in function of satisfying the needs of end users, i.e. beneficiaries.

With the development of electronic trade many changes were introduced in the manner of operations in companies, sales techniques of goods and services, and manners of communication with consumers and suppliers. It can be concluded that electronic trade is the basis of e-economy which implies digitalization of entire economic structure and/or information through computer network, including also Internet (34).

Electronic trade (E-commerce, e-trade) represents one part of electronic business (E-business, e-management). E-business represents broader notion which includes higher areas of application, which means not only trade, but also business operations on Internet, taking care of services beneficiaries, business partners, etc. The expression electronic commerce was introduced for the first time by American company IBM in order to define operation with significant application of modern, electronic technology. Until then, this expression was related to operations in electronic sector.

E-trade represents only part of e-commerce which is directly related to purchase or sale of goods through computer and Internet network.

Principle of e-trade is identical with principle of classical trade, and the only difference is in means of production. Both kinds of trade have identical goal to deliver the right product to the buyer, with the smallest costs. E-trade is, unlike classical one, based on business communication, purchase/sale and transfer of funds via computers 
and network, with the use of digital communication. It is considered as integral part of e-commerce which, besides e-trade, includes also electronic payments, electronic communications, electronic production and electronic distribution. E-trade represents one of the most popular and most represented types of electronic commerce in the world and in the last few years is the initiator of world economy growth (24).

E-trade involves all activities of purchase and sale of products and services via Internet or other means of electronic communication and consists of distribution, purchase, sale, marketing and services for products and services through electronic systems like Internet. On line tradesman is agent between producer and buyer, and offers to them products and services produced by others.

E-trade is exchange of business information, establishment of business relations and management of business transactions between various organizations through telecommunication networks and represents little bit more than group of Internet technologies. E-trade is the basis for the existence of electronic trade. Major changes occur in the manner of doing business, e-trade and Internet become every day thing, which enables introduction of new, digital revolution.

In the period of constant market and competition growth, understanding and satisfying the needs of e-trade beneficiaries became imperative. Level of use of information technology and computers in e-trade depends upon numerous factors. One of them is also legal regulative which regulates this area of business. In the paper is indicated the significance of legal regulation in inducement of expansion of usage of e-trade among citizens of Republic of Serbia, which creates area for more intense impact of e-trade system.

The subject of this paper is examination to which extent and in which manner legal regulative through safety and privacy impacts over usage of e-trade in Republic of Serbia. This question is very important having in mind the importance of e-trade in modern business conditions. According to defined topic of research, the main goal of this paper is identification of impact of legal regulation to the degree of use of e-trade in Republic of Serbia. Also, the objective of this paper is also overview of the areas which should be improved and advanced in order to increase the usage of e-trade in Republic of Serbia.

According to established goals of the research and overview of the literature, we are starting from the following hypothesis in this paper:

Hypothesis 1:

Good legal regulation has positive impact over the usage of electronic trade.

Hypothesis 2:

Legal regulative has direct impact over increased safety of electronic trade.

Hypothesis 3:

Safety of electronic trade has direct impact over usage of electronic trade.

Hypothesis 4:

Legal regulation has direct impact over safety regarding privacy of data during electronic trade.

Hypothesis 5:

Privacy of data in electronic trade has direct impact over the use of electronic trade. 


\section{Electronic trade in Serbia}

Massive development and application of Internet impacted over motivation of wider number of users that in search for more economical and more efficient work use also possibilities which are provided by e-trade.

Electronic technology means combined usage of information technology and telecommunications which enables transfer of large number of information to far away destinations in short time period. In such manner company which uses electronic technology in its operations creates significant savings in operation costs, performs tasks more efficiently and therefore becomes more competitive on the market.

Application of modern electronic communication means and computers, every contemporary business system should strive towards communication through electronic information and data, as well as to exchange electronically verified documents.

E-trade means usage of various forms of information and communication technology in business processes between subjects which are engaged in trade, production and service sector, providers of information, government bodies and consumers. Additional stimuli for development of e-trade, besides through Internet, should be established also through liberalization of telecommunications.

E-trade covers all activities of buying and selling of products and services which are performed through Internet or other channels of electronic communication. Above all, e-trade consists of distribution, purchase, sale, marketing and product and services providing through electronic systems like Internet (32).

E-trade enables wide spectrum of improvements, like: faster finding the most favorable bidder of desired product or service at any destination which performs service in optimal time frame, more accessible business transactions related to marketing, design, production, supply chain and transportation. Therefore, possibilities are created for interactive communications and among consumers which were never previously involved in business transactions. New business opportunities become available, which create new forms of increase of productivity, costs reduction and new forms of approach to clients. E-trade and contracts signed via electronic trade (E-contracts) as formal legal instruments of such trade, enable faster economic growth and possibility for Republic of Serbia to compete with much bigger states and their economies, especially in business world where geographical location losses its importance. It represents one of the main reasons for creating safe legal ambiance for e-trade in domestic and international operations, which can contribute to integration of Republic of Serbia into world IT societies. (16)

E-trade is one industry branch in Serbia which in every previous year records growth. One of main characteristics of e-trade in Serbia, as well as in the region is that citizens mainly decide to purchase on international web sites. Participation of purchase on international web sites compared to domestic web sites, is in percentages $90: 10 \%$ (8).

Presence of computers in Serbia increased from 50,4\% in 2010. (10) to 65,8\% in 2016 (11), while presence of Internet at the same period grew from $39 \%$ to $64,7 \%$.

According to one research (26) around one half of citizens in Serbia use Internet on daily basis, mostly via computers and lap tops (90\%), but as well as via smart phones $(57 \%)$. Although Internet is mostly used for searching of information and communications (over $70 \%$ ), around $25 \%$ of citizens of Serbia use it for online purchase of products and 
services. Nevertheless, 56,4\% of Internet users never bought/ordered goods or services online (4). That percentage of online buyers among Internet users is less in Serbia than in in most EU countries, which indicates small development of electronic trade market in Serbia. Therefore, $25 \%$ of Internet users plans to use it in the future, and half of those who do not buy search products and services online, indicating thus great potential for e-trade development. Young, highly educated and citizens with high incomes mostly use e-trade. The items mostly purchased are clothes, shoes and tools, than electronics. Due to safety/ protection reasons pay on delivery is preferred, although paying via cards is considered to be the easiest and fastest way of payment. The question of legal arrangement of e-trade opens question of arrangement of new systems of paying (online paying via debit cards, digital money, system of online current accounts, digital current and check accounts, etc.). Internet payments make the procedure easier, save time and opens question of strengthening of convictions among citizens in safety of such payment mechanisms. (17) As the most important reasons for choosing online shopping, we can stress: delivery to home address, easier possibility for comparing offers, no working hours, and better choice. High costs of delivery, incorrect information on product and delivery of products which do not comply with expectations are stressed as main obstacles facing online consumers in Serbia. Low level of trust in safety of such manner of shopping and risks which are related to it, are the key reasons why great number of questioned buyers never purchased via Internet. Still there is a great distrust in safety of use of debit cards online on Internet and great suspicion regarding quality of presented products, and that what was ordered would be delivered for real.

In spite of constant growth, there are significant obstacles for further growth of e-trade in Republic of Serbia. One of the biggest obstacles is the fact that Serbia as a state does not have prepared plan for further development of electronic trade.

Legal regulative of electronic trade (E-regulative)

Creating the ambiance for higher impact and application of the system of e-trade is conducted, to a higher extent, through implementation of legal regulations in the field. Through creation of conditions for application of electronic signature and exchange of electronic documents with the trust of the widest public in the use of electronic signature and application of electronic payment, which demonstrates efficiency of domestic electronic regulative.

Comparing to countries in European Union, Republic of Serbia was relatively late involved in regulation of subject matter, but in the last few years this activity was increased. It was created legal framework coherent with EU legislative, which clearly depicts determination of Republic of Serbia towards EU membership.

Domestic legal regulation of e-trade consists of Law on electronic signature (56), Law on electronic document (54), and Law on electronic trade (52) which initiated the process of creation of harmonized, incorporated legal framework for e-trade in Republic of Serbia.

Process of creation of legal framework for regulating of e-trade area initiated with enactment of Law on electronic signature which is in full accordance with Directive 1999/93/EC (1), which had the goal to establish criteria for legal recognition of electronic trade in member states.

The main role of Law on electronic trade is prescribing conditions under which electronic signature is legally equal to personal signature, as well as conditions which 
must be full filled by certification bodies which issue qualified certificates for verification of electronic signatures. Law has the goal to create legal framework necessary for successful establishment, functioning and development of information society.

Electronic signature is determined as group of data in electronic form which are joined or logically linked with electronic document, and serve to identify signatories (56). Digital electronic signature reliably guarantees identity of signatory, prevents disturbance of integrity of electronic document and disables later denying of responsibility for the content of the document. Law introduces the notion of qualified electronic data, which compared to data in electronic format, has the same legal effect and proved power as the personal signature or personal signature and stamp, related to data in paper format, with fulfilment of conditions defined by law (56). Law was adopted in order to strengthen electronic operations as a whole, but its implementation had the goal to create trust of the widest public for the use of electronic signature and exchange of electronic documents.

According to the Law on electronic trade (52) electronic document is a group of data contained from symbols from the act created by physical or legal bodies in order to use in legal trade, if it was created electronically (57). According to the Law on electronic document it cannot be disputed validity or the proof importance only because it is in electronic format.

Enactment of the Law on electronic trade (52) creates conditions for functioning of the system of electronic trade with the acceptance of the solution of Directive of electronic trade (2). The Law equalizes and adjusts electronic trade to the existing, classical form of purchase (15). Law on trade (61), represents general legal act comparing to Law on electronic trade which represents special legal act. Law on trade defines trade as group of business activities of trade that is buying and selling of goods, or services on the market with the goal to gain profit, as well as other social or economic goal. Trade can be performed as a wholesale or retail trade. Wholesale trade represents group of all business activities related to sale of goods and services to individuals which purchase in order to sell further or to use it for business purposes, while retail is related to sale of goods and services to consumers in order to satisfy personal needs or needs of household. According to the place of sale, trade can be performed in and out of the sales facility. Trade outside of sales facility can be performed as retail trade (mostly performed) and as distant retail trade. Law defines distant retail trade as sale of goods and services performed by the merchant through media of communications to the consumer, who is not present on the spot and that distant retail trade, especially electronic trade, sale via catalogues, and TV sale, trade via regular mail, printed shipments, advertisement materials with mail orders, telephone, text and multimedia messages in mobile phone operating and vending machines. The Law defined electronic trade with goods and services as distant trade (22).

Law on electronic trade defines conditions and the manner of IT society services providing, obligations to inform service beneficiaries, commercial messages, rules related to contracts signing in electronic form, responsibility of IT society service providers, surveillance and violations (61). Service of IT society is the service provided to the distance, with the compensation via electronic equipment for processing and storage of data, on the personal request of service beneficiary, and especially trade via Internet, offering data and advertisement via Internet, electronic browsers, as well as enabling to find data and services which are transferred via electronic network, enabling access to the network or data storage for service beneficiaries. Service provider of IT society 
is legal body or entrepreneur, who provides services of IT society. Consumer is every physical person which enters into legal operation in the market for the purposes which are not intended for performing his occupation. Services providing in IT society is free and for this activity neither special license is necessary, nor approval from the authorized body.

Law defines service beneficiary as physical or legal body which due to professional or other goals uses services of IT society, while consumer is every physical person who enters into legal operations on the market for the purposes which are not intended for performing his occupation. The Law defines contract in electronic format as every contract signed between physical and legal bodies, shipped, received, breach, canceled, accessed and which is presented in electronic format with the usage of electronic devices (61). This Law for the first time introduces in legal system of Serbia the possibility to contract legal operations only via electronic means, and the condition of invalidity is not related to the fact that it is made in electronic format (52). Electronic form of contract is not applied to certain legal operations where is proscribed the use and validation of personal signature on documents in the paper (related to real estate, property relations between spouses, management of the property owned by individuals who were deprived of business capability, contracts on gifts, etc.)

Enactment of mentioned legal regulative, adequate legal framework was created for the development of e-trade in Republic of Serbia. The question which can be posed, is related to further implementation of legal solutions and the question of safety of electronic trade. In systematical legislative activity of arrangement of e-trade, especially is important legal definition of the area of information safety.

Law on information safety (60) defines the area of information safety through definition of measures of protection from safety risks in information and communication systems, responsibilities of legal bodies during systems operations and defining authorized bodies for protection measures conducting. In the law were incorporated principles of Strategy of EU information safety (5), and Proposal of directive on network and information security in EU (NIS Directive) (6). Law defines information-communication system (ICT system), as the system of specific importance in Republic of Serbia, and as such separates ICT systems for public administration bodies, ICT systems where are processed especially sensitive personal data and ICT systems in the public interest activities. Law defines Ministry of trade, tourism and telecommunications as authorized body for information safety. Ministry of defense is authorized for the operations of crypto protection and protection from compromising electromagnetic radiation (KEMZ).

Enactment of the Draft of law on electronic document, electronic identification and services of confidence in electronic operations (7), clearly demonstrates determination of Republic of Serbia to adopt European values and adopted standards of e-trade. Enactment of the new law, will stop the effect of previous laws on electronic signature and electronic document, Subject matter is regulated in the Draft of the new law according to the solutions defined in Statute EU on electronic identification and confident services in electronic transactions (29), which stopped the effects of Directive on electronic signature from 1999. Novelties in the law are related to the area of electronic document, electronic identification, confident services, electronic signature and electronic stamp, time mark, recommended electronic delivery, authentication of web sites and the area of electronic preserving of documentation. 
Besides the work on the enactment of the new law, also was adopted the Strategy for information safety development in Republic of Serbia for the period 2017. - 2020. (adopted on May 27, 2017.), which accepts European standards regarding information safety through proclamation of data protection, information systems, and protection of citizens' safety in digital environment. Strategy separates as priority areas safety of ICT system, information safety of citizens, combat against high tech crimes, information safety of Republic of Serbia and international cooperation. Republic of Serbia has adopted Strategy of development of information society which important part is related to electronic operations and electronic trade. (12) Such activity of Republic of Serbia is the response to taken responsibilities of the members. Initiatives for electronic South East Europe which functions within Stability pact for South East Europe since 2002 (9). E-trade as very important form of international trade demands adjusting of regulation which define international economic and legal transactions via computer technology and Internet network. If we consider regulative of e-trade in neighboring countries, we can conclude that it contains solutions similar to domestic regulative and it is in accord with European Union regulative. In Croatia electronic regulative consists of Law on electronic signature, Law on electronic trade, Law on electronic document, Law on information safety, while in Bosnia and Herzegovina $(\mathrm{BiH})$ electronic operations are regulated by the Law on electronic signature (43) and Law on electronic economic and legal transactions (48). In $\mathrm{BiH}$ are outstanding Law on electronic signature (55) and Law on electronic legal and business transactions (59), while Republic of Srpska has the Law with the same name (49). Slovenian Law on amendments and additions to the law on electronic operations and electronic signature $(50,51)$, contains solutions of Directive on electronic trade of European parliament, which are not present in consumer protection legislative. Macedonia (65) has arranged and adjusted regulative with European Union legislative. In Montenegro electronic regulative consists of Law on electronic trade (53), Law on electronic document (54) and Law on electronic signature (58).

Electronic regulative of European Union can be divided in three basic groups: ICT (information-communication technology) regulative, E-business and intellectual property. Characteristics of this regulative are: obligingness, establishment of minimum of mutual content, horizontal effect and freedom in choice of method of adjustment (14).

Besides Strategy for trade development in Republic of Serbia, Strategy for information safety development in Republic of Serbia for the period 2017. - 2020. and Strategy for information society development for the period 2010. - 2020, outstanding laws and activities on adoption of Law on electronic document, electronic identification and services related to trust in electronic operations, implementation of various aspects of the use of informationcommunication technology is not present enough (33). One of the reasons is the question of safety due to presence of new forms of socially unacceptable behaviors, prohibited, criminal operations in the area of information-communication technology.

\section{Safety of international trade}

Results of the research from 2012, defined the trust in e-trade, quality of offered goods/services and delivery deadlines as the key predictors for generating pleasure among online consumers (20). These satisfaction predictors of online consumers were 
also standing out in this study as the key predictors for taking over the loyalty of online consumers and stimulating of more intense use of e-trade in Serbia.

The attitude of many experts is that the change of distrust atmosphere in the safety of e-trade is the key prerequisite of more intense development of this activity in Serbia. Experts accentuate that all who operate and have the interest in e-trade should work intensively on the creation of atmosphere of trust, whether technical or legal solutions are in question, and weather reputation of those involved in e-trade is in question (28).

Business operations via Internet besides advantages have also some disadvantages, which are manifested through occurrence of certain undesired effects, risks and dangers, so the question of safety of electronic trade in modern time is inevitably posed (37). Forms of prohibited activities in information-communication technology are numerous and various (38). Electronic trade beneficiaries are not enough informed about their rights, measures of protection against such criminal activities, which contributes to their legal insecurity. Serbian criminal legislation from the enactment of the new Criminal Law introduces new criminal acts related to computers and computer networks. Fully are accepted postulates of Convention on cyber-criminal and Additional protocol of the convention, which is clear indicator of the adequate determination of Republic of Serbia in the process of adjusting the legislative and involvement in integration processes.

In the area of information communication technology are present various forms of unlawful, prohibited behavior like computer sabotage focused on destruction of the computer, users programs where data are kept. Then, computer espionage where is deliberately, harmfully discovered business secret with the use of harmful programs (computer viruses). Computer fraud is the most widely present kind of computer criminal deeds, where perpetrator abuses the anonymity, distance, promptness of the job, and therefore obtains some illegal benefit. The subject of the abuse can be identity of and individual, so called identity theft, forging of data and documents, in order to obtain property or any other benefit. In the area of electronic banking are present frauds by the abuse of debit cards, their forgery and theft.

Socially unacceptable behaviors related to computers and computer networks, regarding their international character demand adjusting solutions of national legislatives. The first step in this plan is enactment of Convention on cyber-criminal which as a form of international contract regulates the need to operate mutual criminal policy in the area of combating cyber-crimes. Republic of Serbia ratified the Convention in 2009, and entered its stipulations into Criminal Law (18).

International Convention on cyber-crime was adopted in 2001, and enacted in 2004. Additional protocol with the Convention on cyber-crime and criminalization of acts of racisms and xenophobia performed with means of computer communications, was enacted in 2003, and it demands from countries who signed it criminalization of spreading racist and xenophobic contents via computer devices, as well as racist and xenophobic threats and insults.

The notion of cyber-crime is related to prohibited acts where the use of computers or computer networks are the basis of criminal act. Cyber-crime is not related to criminal acts where computer is present as technical mean for its easier conducting (for example money forging).

Directive on protection of private data defines the right on privacy in the area of electronic communications and free circulation of data, communication equipment and 
services (3). Directive proclaims obligatory provision of safety of services, maintenance of confidentiality of information and was placed out of effect with Regulation EU on protection of individuals regarding processing personal data and free movement of such data and of placing out of effect of Directive (36). These legal regulations serve as the basis of domestic legislative activity and solutions of European regulative are based on the Law for protection personal data (62).

Serbian Criminal legislative from the enactment of the new Criminal Law introduces new crimes related to computers and computer networks. Fully are accepted stipulations of Convention on cyber-crime and Additional protocol of the convention, which is the clear indicator of adequate determination of Republic of Serbia in the process of adjusting the legislative and involvement into integration processes.

Criminal Law of Republic of Serbia defines prohibited activities related to computers and computer networks as criminal acts. Law precisely and in great details quotes criminal acts from the area of computer crimes, and defines them as criminal acts against computer data safety (18).

The Law introduces criminal act of damaging computer data and programs, and defines punishment for every individual which unauthorized erases, alters, damages, covers or in another manner makes unusable computer data or program. Computer sabotage is sanctioned in the manner that defines punishment for everyone who enters, damages, erases, alters, damages, covers or in another way make unusable of computer data or destroys computer with the intention to prevent the procedure of electronic processing and transfer of data which are relevant for state bodies, public services, institutions, companies or other subjects.

Creation and introduction of computer viruses is criminal act of the person who creates computer virus with the intention to introduce it in someone else's computer, as well as of the individual who introduces computer virus in someone else's computer or computer network and therefore creates damage. Computer fraud is introduction of inaccurate data which impacts the result of electronic processing and data transfer in order to provide illegal property benefit to himself or somebody else and therefore produces property damage to someone else.

Unauthorized access to protected computer, computer network and electronic processing of data is criminal act, as well as unauthorized prevention and limitation of access to public computer network. Individual who uses computer services or computer network without authorization with the intention to obtain illegal property benefit for himself or somebody else, performs criminal act defined by the law.

New legally defined criminal act is creation, provision and offering to someone else means for performing criminal acts against computer data safety.

The person which produces and distributes computer programs projected for performing of some criminal act, as well as computer codes for the accession to IT computer system in order to perform some of the mentioned criminal acts, is defined as perpetrator of this criminal act.

Absolute legal safety is not present in any kind of business, so for the e-trade with the characteristics relevant for it, legal uncertainty of its beneficiaries is very much present. The question of legal regulative and harmonization with European and international legal acts can be arranged much easier, than to enforce the same laws and incorporate into practice. Criminal acts against computer data safety have their characteristics: 
virtual, complex technological content, short term of operating (possibility to erase data), international element, etc. These specialties create that criminal acts against computer data safety are often very hard to prove, which is at the same time challenge for more perfect and better legal regulative in order to strengthen safety of e-trade. Incorporation of legal regulative is the manner of strengthening of legal safety of e-trade beneficiaries. When laws are enacted in practice, the trust of e-trade beneficiaries will increase.

\section{The impact of legal regulative to the use of electronic trade in Republic of Serbia}

\section{Research model}

Having in mind analyzed variables and defined hypothesis, we can also define conceptual model of the research. It is applied modified version of electronic model of index of consumer satisfaction, which is developed on the basis of ACSI model (developed by Taiwan economist, S. H. Hsu (13), and according to it trust and quality of electronic service are the most important inducers of online consumers' satisfaction. The model created has the primary goal analysis of interrelations in the relation legal safety - safety - privacy - intensity of e-trade use.

Within the model we can see that variable which is related to legal regulative impacts attitudes of consumers regarding safety and privacy, and that these two variables impact the intensity of e-trade use. All mentioned relations are represented on Figure 1.

Figure 1: Conceptual model of research

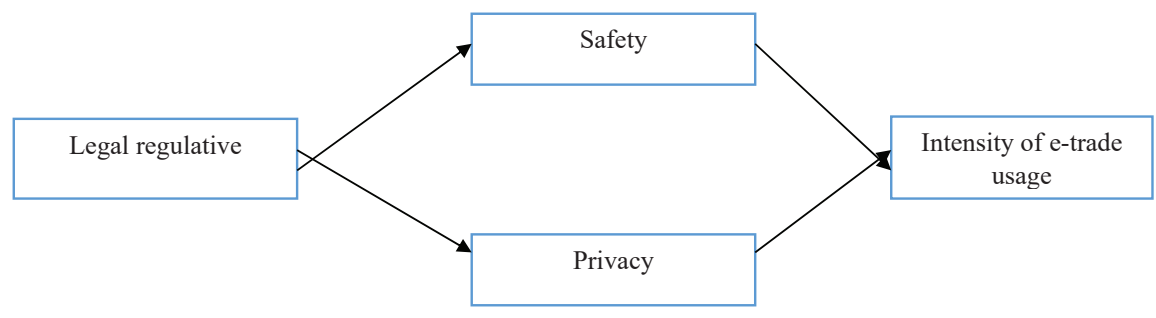

Source: Authors

\section{Methodology of research}

In order to analyze previously established links, we have conducted the research on the territory of city of Kragujevac. The research was conducted during May and June, 2017, and 86 valid polls were gathered. Structure of the sample according to socio-demographic characteristics is represented in Table 1 . We can observe that most of the respondents in the sample are of male sex. Besides, majority of questioned belong to younger generation, with high education. Data were gather through distribution of questionnaires personally, where respondents estimated the degree of their consent with mentioned claims on seven degree Likert scale (where 1 - I strongly disagree, 7 - strongly agree).

Statistical processing and analysis of data was performed with the use of software packages Microsoft Excel and SPSS (Statistical Package for Social Sciences, 21.0). 
Out of statistical analyses, firstly it was used analysis of descriptive statistics, then explorative factor analysis, which grouped affirmations into factors, whose interrelations were observed. As the measure of internal consistency of affirmations within factors, Cronbach's alpha coefficient was used. Assumed relations between factors were analyzed via simple and multiple linear regression. For measuring of statistically significant differences between attitudes of respondents of various groups were used t test of independent samples, as well as one factor variance analysis - ANOVA.

Table 1: Descriptive statistics for respondents' characteristics

\begin{tabular}{lcc}
\hline & & \% of respondents \\
\hline \multirow{2}{*}{ Age } & Male & 75.6 \\
& Female & 24.4 \\
& Up to 20 years & \\
& $21-30$ & 2.3 \\
& $31-40$ & 97.7 \\
Education & $41-50$ & \\
& Over 50 & 31.4 \\
& Secondary education & 1.2 \\
Occupation & College & 67.4 \\
& University degree & 97.7 \\
& Student & 2.3 \\
\hline
\end{tabular}

Source: Author's calculation

\section{Results of the research}

In order to group affirmations from the questionnaire into factors, we performed explorative factor analysis. This analysis derived four factors, which are related to observed variables in research model. Value of Cronbach's alpha coefficient is higher for every factor from recommended value of 0.7 , which demonstrates that factors have good internal consistency. Values of factor burdens in every factor, as well as values of Cronbach's alpha coefficient for each factor are represented in table 2.

Indices which should be taken into account during evaluation of justification of implementation of explorative factor analysis are Bartlett's sphericity test and KaiserMeyer-Olkin (KMO) test for sampling adequacy. Value of KMO indicator in case of this research is 0,687 , while Bartlett's test of sphericity has statistically significant value (Sig. $=0,000)$, which indicates that the use of factor analysis is justified. Total percentage of variance which is explained via these four factors is $69,31 \%$. 
Table 2: Results of explorative factor analysis

\begin{tabular}{lcc}
\hline Affirmations & Factor loading & $\boldsymbol{\alpha}$ \\
\hline Legal regulative & & 0.702 \\
\hline
\end{tabular}

0.742

I think that there is good legal safety of electronic transactions and electronic data.

I think that there is good protection of information

infrastructure from hackers' attacks.

I think that there is well organized combat against high-tech (computer) crime.

I trust in the measures of current legal regulation for online purchases in Serbia.

$$
0.638
$$

\begin{tabular}{lcc}
\hline Safety & 0.789 \\
\hline
\end{tabular}

Web site provides inaccessibility of information to unauthorized persons and confidentiality.

Web site provides consistency of data, through preventing unauthorized generation, alteration and destruction of data integrity.

Web site provides that authorized users can always use services and access to information - accessibility.

Web site provides enough information regarding safety issues.

0.654

\begin{tabular}{lcc}
\hline Privacy & 0.715 \\
\hline & 0.678
\end{tabular}

I think that monitoring of habits in online trade by electronic merchants is not the kind of privacy endangering. I think that preserving data on IP address of the computer and data on device is not privacy endangering.

I think that there is no risk from endangering privacy during ordering goods online - entering first and last name, address, phone number

It is not the problem, when demanded, to leave current account number and debit card number in order to perform purchase online.

0.624

\begin{tabular}{lc}
\hline Intensity of e-trade use & 0.865 \\
\hline
\end{tabular}

I am the consumer which uses the benefits from e-trade to a maximum.

I perform many purchases on Internet.

I use more online than classic trade.

Electronic trade makes my purchase easier.

0.752

Bartlett's test of sphericity

Sig. $=0,000$

$\mathrm{KMO}$

0,687

Source: Author's calculation 
Results of descriptive statistics for factors and belonging affirmations were presented in Table 3. According to these results, we can observe that respondents gave the highest score to affirmation related to affirmation - Web site provides that authorized users can always use services and access to information - accessibility. (AS = 5,6279, $\mathrm{SD}=1,19849)$. On the other side, the lowest score was given to affirmation - I use more online than classic trade. ( $\mathrm{AS}=3,0698, \mathrm{SD}=2,03378$ )

Table 3: Results of descriptive statistics analysis

\begin{tabular}{|c|c|c|}
\hline Affirmations & AS & SD \\
\hline \multicolumn{3}{|l|}{ Legal regulative } \\
\hline $\begin{array}{l}\text { I think that there is good legal safety of } \\
\text { electronic transactions and electronic data. }\end{array}$ & 4.6395 & 1.25476 \\
\hline $\begin{array}{l}\text { I think that there is good protection of } \\
\text { information infrastructure from hackers' attacks. }\end{array}$ & 4.4535 & 3.38737 \\
\hline $\begin{array}{l}\text { I think that there is well organized combat } \\
\text { against high-tech (computer) crime. }\end{array}$ & 4.0349 & 1.25976 \\
\hline $\begin{array}{l}\text { I trust in the measures of current legal regulation } \\
\text { for online purchases in Serbia. }\end{array}$ & 4.0930 & 1.53107 \\
\hline \multicolumn{3}{|l|}{ Safety } \\
\hline $\begin{array}{l}\text { Web site provides inaccessibility of } \\
\text { information to unauthorized persons and } \\
\text { confidentiality. }\end{array}$ & 4.8837 & 1.49838 \\
\hline $\begin{array}{l}\text { Web site provides consistency of data, through } \\
\text { preventing unauthorized generation, alteration } \\
\text { and destruction of data - integrity. }\end{array}$ & 4.7209 & 1.15454 \\
\hline $\begin{array}{l}\text { Web site provides that authorized users can } \\
\text { always use services and access to information } \\
\text { - accessibility. }\end{array}$ & 5.6279 & 1.19849 \\
\hline $\begin{array}{l}\text { Web site provides enough information } \\
\text { regarding safety issues. }\end{array}$ & 4.9302 & 1.36158 \\
\hline \multicolumn{3}{|l|}{ Privacy } \\
\hline $\begin{array}{l}\text { I think that monitoring of habits in online } \\
\text { trade by electronic merchants is not the kind } \\
\text { of privacy endangering. }\end{array}$ & 4.8256 & 1.73674 \\
\hline $\begin{array}{l}\text { I think that preserving data on IP address of } \\
\text { the computer and data on device is not privacy } \\
\text { endangering. }\end{array}$ & 4.1977 & 1.71375 \\
\hline $\begin{array}{l}\text { I think that there is no risk from endangering } \\
\text { privacy during ordering goods online - entering } \\
\text { first and last name, address, phone number }\end{array}$ & 4.1860 & 1.84398 \\
\hline $\begin{array}{l}\text { It is not the problem, when demanded, to leave } \\
\text { current account number and debit card number } \\
\text { in order to perform purchase online. }\end{array}$ & 3.2442 & 1.90933 \\
\hline \multicolumn{3}{|l|}{ Intensity of e-trade use } \\
\hline \multirow{5}{*}{$\begin{array}{l}\text { I am the consumer which uses the benefits } \\
\text { from e-trade to a maximum. } \\
\text { I perform many purchases on Internet. } \\
\text { I use more online than classic trade. } \\
\text { Electronic trade makes my purchase easier. }\end{array}$} & 3.8372 & 1.80757 \\
\hline & 3.7909 & 1.93492 \\
\hline & & \\
\hline & 3.0698 & 2.03378 \\
\hline & 4.7442 & 1.99521 \\
\hline
\end{tabular}


In order to examine established hypotheses, two simple, two dimension and one multiple regression analyses were used. Namely, via these analyses was examined impact which legal regulative has on attitudes regarding safety and privacy, as well as impact which these two variables have over intensity of the use of e-trade. Results of these analyses were represented in Tables 4, 5 and 6.

Results of simple linear regression were presented in Table 4, and indicate that regulative has positive and statistically significant impact over attitudes of consumers regarding safety of e-trade use $(\beta=0,256$. Sig. $=0,017)$.

Table 4: Results of simple linear regression (dependent variable - attitudes of consumers regarding safety of the use of $\mathrm{e}$ - trade)

\begin{tabular}{ccccccc}
\hline Hypothesis & Variable & R Square & F & $\boldsymbol{\beta}$ & t & Sig. \\
\hline H & Legal regulative & 0.256 & 15.887 & 0.256 & 2.426 & 0.017 \\
\hline
\end{tabular}

Source: Author's calculation

The impact of legal regulative over attitudes of consumers regarding privacy was examined also through simple, linear regression, and results of this analysis were presented in Table 5. Based on these results, we can observe that legal regulative has positive and statistically significant impact over attitudes of consumers regarding privacy in use of e-trade $(\beta=0,285$, Sig. $=0,008)$.

Table 5: Results of simple linear regression (dependent variable - Attitudes of consumers regarding privacy of $\mathrm{e}-$ trade use)

\begin{tabular}{ccccccc}
\hline Hypothesis & Variable & R Square & F & $\boldsymbol{\beta}$ & t & Sig. \\
\hline H & Legal regulative & 0.285 & 17.444 & 0.285 & 2.728 & 0.008 \\
\hline
\end{tabular}

Source: Author's calculation

Examination of impact of attitudes on safety and privacy over intensity of e-trade use was performed via multiple regression analysis, which results were represented in Table 6. Namely, mentioned analysis demonstrated that factor which is related to privacy has positive and statistically significant impact over intensity of the use of e-trade ( $\beta=$ $0,300$, Sig. $=0,010)$. On the other hand, factor which is related to safety has positive, but not statistically significant impact over intensity of e-trade use $(\beta=0,015$, Sig. $=0,896)$

Table 6: Results of multiple linear regression (dependent variable - Intensity of e-trade use)

\begin{tabular}{cccccc}
\hline Hypothesis & Variable & $\boldsymbol{\beta}$ & $\mathbf{T}$ & Sig. & VIF \\
\hline H & Safety & 0.015 & 0.1322 & 0.896 & 1.172 \\
\hline H & Privacy & 0.300 & 2.2628 & 0.010 & 1.185 \\
\hline
\end{tabular}

Source: Author's calculation

Besides mentioned results, we should stress that multi collinearity is not a problem in presented analyses, regarding that the factor of variance growth (VIF) is less than recommended value of 5 , in case of impact of both factors on intensity of e-trade use (Field, 2000). 
Examination of statistically significant differences between attitudes of respondents towards privacy and safety of e-trade use was performed via t-test of independent samples, as well as via one-factor variance analysis. Results of analysis of statistically significant differences between attitudes of respondents of male and female sex are presented in Table 7. Namely, according to the presented results we can observe that statistically significant differences between respondents' attitudes according to the criteria of sex does not exist in case of respondents' attitudes on legal regulative, safety, as well as privacy in use of e-trade services. Nevertheless, also can be observed from presented results, is that respondents of both sexes demonstrate more positive attitudes regarding safety of use of mentioned services $\left(\mathrm{AS}_{\text {male }}=5,0231, \mathrm{AS}_{\text {female }}=5,0952\right)$, compared to attitudes towards legal regulative $\left(\mathrm{AS}_{\text {male }}=4,1192, \mathrm{AS}_{\text {female }}=4,3952\right)$. Besides, results indicate that statistically significant differences between respondents' attitudes occur regarding intensity of e-trade services use $(\mathrm{t}=2,551$, Sig. $=0,043)$. It can be observed that male population has more positive attitude on intensity of use of such services ( $\left.\mathrm{AS}_{\text {male }}=4,3690, \mathrm{AS}_{\text {female }}=3,6962\right)$.

Table 7: Results of $\mathrm{t}$ test for two independent samples

\begin{tabular}{|c|c|c|c|c|c|c|}
\hline & \multicolumn{2}{|c|}{ Male } & \multicolumn{2}{|c|}{ Female } & \multirow[b]{2}{*}{ t value } & \multirow[b]{2}{*}{ Sig. } \\
\hline & AS & SD & AS & SD & & \\
\hline Legal regulative & 4.3077 & 1.33812 & 4.2976 & 1.22632 & 0.031 & 0.976 \\
\hline $\begin{array}{c}\text { Safety } \\
\text { Privacy } \\
\text { Intensity of use }\end{array}$ & $\begin{array}{l}5.0231 \\
4.1192 \\
4.3690\end{array}$ & $\begin{array}{l}0.88579 \\
1.22712 \\
1.89674\end{array}$ & $\begin{array}{l}5.0952 \\
4.3952 \\
3.6962\end{array}$ & $\begin{array}{l}1.12215 \\
1.54612 \\
1.52869\end{array}$ & $\begin{array}{l}0.303 \\
0.073 \\
\mathbf{2 . 5 5 1}\end{array}$ & $\begin{array}{l}0.762 \\
0.942 \\
\mathbf{0 . 0 4 3}\end{array}$ \\
\hline
\end{tabular}

Source: Author's calculation

Examination of statistically significant differences between attitudes of respondents of different groups regarding observed aspects of use of e-trade services in the sample was performed through one factor analysis of variance. Results of this analysis were presented in Table 8. According to these results, it can be observed that statistically significant differences occur regarding attitudes on safety, between groups of respondents according to the criteria of age $(F=1,955$, Sig. $=0,046)$, as well as regarding attitudes on intensity of use of e-trade services, between groups according to the criteria of occupation of respondents $(F=2,774$, Sig. $=0,010)$, while regarding legal regulative and privacy of use of these services there are no statistically significant differences between groups of respondents.

Table 8: Results of one factor analysis of variance

\begin{tabular}{ccccccc}
\hline & \multicolumn{2}{c}{ Age of respondents } & \multicolumn{2}{c}{ Occupation } & \multicolumn{2}{c}{ Education of respondents } \\
\hline & F value & Sig. & F value & Sig. & F value & Sig. \\
\hline Legal regulative & 0.006 & 0.940 & 1.732 & 0.192 & 1.595 & 0.209 \\
Safety & & & & & & 0.185 \\
$\quad$ Privacy & $\mathbf{1 . 9 5 5}$ & $\mathbf{0 . 0 4 6}$ & 1.162 & 0.284 & 1.720 & 0.524 \\
Intensity of use & 0.179 & 0.674 & 0.015 & 0.990 & 0.652 & 0.568 \\
\hline
\end{tabular}

Source: Author's calculation 
Having in mind that it is established that there are statistically significant differences between attitudes of respondents regarding safety and intensity of use of e - trade, via post-hoc and Hukey HSD test was examined among which groups are these differences present. These tests indicated that differences regarding aspects of safety are between group of respondents between 21 and 30 years of age (AS $=5.0625, \mathrm{SD}=$ $0,940)$, as groups of respondents of the age up to 20 years $(\mathrm{AS}=4,1250, \mathrm{SD}=0,530)$. Besides, regarding the intensity of use, statistically significant differences occur between groups of students $(\mathrm{AS}=3,815, \mathrm{SD}=1,632)$ and respondents who belong to the group of employees $(\mathrm{AS}=5,750, \mathrm{SD}=0,353)$.

\section{Conclusion}

Internet market has the status of the market with the biggest potential on the global scale. Electronic trade in Serbia has the potential, but is not developed to the extent to which it could be. Until 2000, it was considered that the problem of under developed information infrastructure and lack of legal framework was the main obstacle for e-trade development in Serbia. In the period 2000-2010, situation was significantly improved thanks to investments in development of the fast Internet and significant improvement of legal regulative. Enactment of the Law on electronic trade in 2009 created conditions for more dynamic development of this segment of trade activity (39). The problem of lack of trust is the main obstacle for faster growth of e-trade in Serbia in the future. Safety of data and information systems in general is one of the priority tasks of legal system of every state which is under influence of Information technology and obtained global dimension (63). Problem solving regarding lack of trust should not be observed in narrow manner, at the level of Serbia, but in global context. Increase of trust in safety of online shopping is of utmost importance for the development of e-trade in Serbia. Electronic trade and its development at the level of Serbia is significant, not only from the standpoint of transformation of its economy in developed information society, but also due to the fact that it impacts intermediary on the increase of employment (30). Reasons for low level of e-trade in Serbia should be looked above all in widely spread sense of distrust which is created due to the result of fear from possible fraud at such kind of trade. Such fear is the result of several factors, and out of them the following are (and 28):

1. Lack of trust in state bodies which should vouch for reliability and fairness;

2. Low level of trust is also very deeply rooted in templates of social behavior of citizens of Serbia;

3. Distrust is developed as natural mechanism of protection from risk to which people are exposed in everyday life.

The first two represent specifics of Serbian society, while the last reason can be placed in category of universal factors.

Regarding e-trade in Serbia, beneficiaries still do not have enough trust in order to use their debit cards on Internet. Small percentage of population which already uses Internet use debit cards for online payments. Also, beneficiaries do not have enough trust in most of sales on Internet in order to provide personal information in exchange for the approach to certain information. Beneficiaries reluctantly provide these information 
especially when they consider that their privacy is endangered. Especially are worried due to impossibility to control the use of these information and data. The most frequent risks of e-trade are derived from (36):

1. Abuse and destruction of data,

2. Violation of privacy of clients.

Risks can be avoided with the use of adequate measures of information safety. Information safety is protection of interests of subjects of information relationships and consist of measures at four levels: legislative, administrative, procedural and program-technical (64).

According to the research among Internet beneficiaries, safety of web sites is the most important factor for accepting online purchase, and reputation of web site/company and recommendation are the most important indicators of safety for web sites (26). On the other side, there are researches in Serbia which demonstrated that increase of safety/ privacy does not contribute to satisfaction with quality of service which should lead to the increase of the use of e-trade (23).

According to one research $67 \%$ of respondents in Serbia consider that there is a risk from fraud and misuse of accounts but besides it they use e-trade (20). Only $10 \%$ of respondents think that there is full safety during the use of e-trade. It is interesting that the same percentage of older and younger respondents consider this type of trade as the safe one.

Increase of the level of trust as well as decrease the risk of e-trade can be, besides other, achieved through adequate legal regulative in the area of e-trade which would make beneficiaries feel safer and more protected during online shopping. It is obvious that problem solving is under authority of state bodies. If we adopt as soon as possible and start to implement adequate laws and accept other submitted propositions for economically more stimulating surrounding, which will create more favorable ambiance for the development of e-trade and Internet trade in Serbia.

Experiences of market oriented countries demonstrate that governments of these countries evade big and unnecessary restrictions in business activities, including e-trade. Mostly are defined minimally necessary conditions for functioning of legal surrounding, together with formal and legal understanding of the importance of Internet (19). Such experiences should be used during creation of adequate ambiance for development of e-trade in Serbia.

On the other hand, for the development of e-trade are important also factors which impact the satisfaction of e-trade users. These factors include effects during entire process of decision making: from registration to the merchant's web site, through ordering and use of products/services, up to the use of after sale services (21). In each phase of the process of decision making regarding sale, beneficiary can become frustrated and demotivated, which can impact his desire to purchase over this merchant's e-trade site. In order to avoid number of cancelled shopping it is necessary to act preventively, to measure the satisfaction of beneficiaries and according to that to increase the quality of e-trade.

Many models for measuring and improvement of e-trade (SITEQUAL (42), eTailQ (41), E-S-QUAL (27)) research and stress impact of safety and protection of privacy of data as important factors which impact the quality of services of e-trade, and therefore the satisfaction with the use of e-trade. 
Most of small and medium enterpises in Serbia does not offer their products/ services online. Those who perform it mostly offer their products/services via web sites for advertisement or on their own web sites, and sometimes also via social networks and do not inform enough beneficiaries on those activities. Most of those companies use classic trade because they think that lack of possibility to try the product is ethe main obstacle for users to buy online (26).

Results of conducted reseach for the needs of this paper demonstrate that legal framework has positive impact over safety and privacy during the use of e-trade, and that safety and privacy have positive impact on the intensity of e-trade use.

Having in mind previous facts, we could conclude that only mutual interaction of state authorities and e-merchants in the area of legal regulative, safety and privacy protection led to increased satisfaction of e-trade beneficiaries and its wider application. Also, better information of citizens as well as better acknowledgement of possibility of online sale by small and medium entreprizes, which can increase number of e-trade beneficiaries.

Finaly, we can conclude that safety of e-trade and trust in it, key factors to take over loyalty of online of consumers and stimulation of more intense use of e-trade. Creation of various strategies for development of information society in Serbia, and not creating the atmosphere of trust and adequate legal framework, hardly can contribute to more significant progress in the domain of e-trade in our country and reaching of European Union average progress.

\section{References}

Directive 1999/93/EC of the European Parliament and of the Council of 13 December 1999 on a Community framework for electronic signatures, OJL 13, 19.1.2000, p. $12-O 2$.

Directive 2000/31'/EC of the European Parliament and of the Council of 8 June 2000 on certain legal aspects of information society services, in particular electronic commerce, in the Internal Market ('Directive on electronic commerce'), Official Journal of the European Communities (OJL) 178, 17. 07. 2000, p. 1-16.

Directive 95/46/EZ of European Parliament and Council dated October 24, 1995. regarding the protection of individuals regarding processing personal data and free flow of such data, OJ L 281, 23.11.1995, p. 31-50

http://www.stat.gov.rs/WebSite/repository/documents/00/02/25/86/IKT 2016 pres_s.pdf/ preuzeto 8.6.2017.

http://eeas.europa.eu/archives/docs/policies/eu-cyber-security/cybsec_comm_en.pdf http://eeas.europa.eu/archives/docs/policies/eu-cyber-security/cybsec_directive_en.pdf http://mtt.gov.rs/download/Nacrt.pdf

http://www.euractiv.rs/srbija-i-eu/6923-sve-popularnija-e-trgovina прегледано: 22. јула, 2015. године.

http://www.ncd.matf.bg.ac.rs/news/en/eSEE_Agenda.pdf

http://www.stat.gov.rs/WebSite/repository/documents/00/02/29/10/17 Informacione_tehnologije.pdf/preuzeto: 8.6.2017 
http://www.stat.gov.rs/WebSite/repository/documents/00/02/25/86/IKT_2016_ pres_s.pdf/preuzeto:8.6.2017.u 14.05.

www.srbija.gov.rs

Hsu, S-h., (2008), Developing an index for online customer satisfaction: Adaptation of American Customer Satisfaction Index, Expert Systems with Applications, Vol. 34, 3033-3042.

Knežević, M., (2010) ,Responsibility for fulfillment of contracts signed electronically, Law and economy, Association of lawyers in Serbian economy, Belgrade, Number 7-9/2010, ISSN 0354-3501, p. 144-154.

Knežević, M., (2015), „Specificities of Electronic Contracts”, Calitatea-acces la succes, Vol 16 (147/August), str. 106-112.

Knežević, M., Lukić, A, (2012) ,Electronic Business Operations on the Banking Market in Serbia and Countries in the Region, International journal of advances in management and economics, Vol. 1, no. 4 стр. 102-107.

Knežević, M., Spalević, Ž. (2012) ,Electronic letters of credits in banking operations in Serbia, Law and services, editor Miodrag Mićović, Kragujevac: Faculty of law University of Kragujevac, Institute for legal and social sciences, p. 255-269.

Criminal Law, "Official gazette of RS", no. 85/2005, 88/2005 - correction. 107/2005 - correction. 72/2009, 111/2009, 121/2012, 104/2013, 108/2014 and 94/2016.

Lečić-Cvetković D., Kostić-Stanković, M., Maslić, V. (2012) ,Research of Customer Satisfaction with the Electronic Postal Services in Serbia, Metallurgies International, Romanian Metallurgical Foundation, 17/7, 176-184

Lecic-Cvetkovic, D., Omerbegovic-Bijelovic, J., Skakic, I., Customer Satisfaction With E-Commerce Services in Serbia at the Beginning of the 21 Century, available at http://om.fon.bg.ac.rs/wp-content/uploads/2013/05/R6-FINes-170313-Rad1-DLCJOB-IS.pdf

Leković, S., (2011), Measuring Customer Satisfaction in E-commerce (in Serbian), Conference SymOpis, Proceedings book, Zlatibor, 259-263

Lučić, Lj. (2011) ,Legal framework for electronic operations in Republic of Serbia, Legal notion, Association of jurists of Republic of Srpska, Banja Luka. no. 28, p. 657-687.

Mihajlovic, N. (2017), The Analysis of Serbian Customers Satisfaction with E-Service Quality Dimensions Of Lodging E-Intermediaries, The European Journal of Applied Economics, 14(1), Singidunum University, Beograd, 48-62

Milić, M., (2011), Factors of success in implementation of electronic trade, INFOTEHJAHORINA Vol. 10, Ref. F-6, p. 927.

Knežević, M.(2015), Specificities of Electronic Contracts, Calitatea-acces la succes, Vol 16 (147/August), p. 106-112.

Oblaković, M., Lazić, A., Panić, S., Mamula, T. (2015) ,Study on E-consumer incentives and barriers in Serbia, Result 2.5 e-Consumer Promotion and Protection, MASMI, Project „E-Business Development,, Beograd,

Parasuraman A., Zeithaml Valarie A., Malhotra A., (2005), E-S-QUAL: A MultipleItem Scale fir Assessing Electronic Services Quality \& Reliability Management, Journal Of Services Research, Elsevier, Vol. 14, No. 3, pp. 204-218. 
Petrović, D., Kovačević, I., (2012), Lack of trust as the obstacle to e-trade development in Serbia, Management - Paper for theory and practice of management, FON, p. 71-77.

Regulation (EU) No 910/2014 of the European Parliament and of the Council of 23 July 2014 on electronic identification and trust services for electronic transactions in the internal market and repealing Directive 1999/93/EC, OJ L 257, 28.8.2014, p. $73-114$.

Simovic, V., (2013), The potential of the e-business and specialized internet services in terms of reducing the level of unemployment in Serbia, Economic Sciences on the Crossroad: proceedings from the international conference. Belgrade: Institute of Economic Sciences, 2013, p. 641-651.

Strategy of information safety for further strengthening of digital protection, adopted on May 27, 2017.

Todorović, J., Lečić-Cvetković, D.,(2006), Product management, Fon, Belgrade.

Tomić-Petrović., N., Petrović, D., (2011), Legal and cultural assumptions for the development of electronic trade in Republic of Serbia, XXIX Symposium on new technologies in postal and telecommunication traffic - PosTel 2011, Transportation faculty University of Belgrade, Belgrade, p. 67-76.

Turban, E., King, D., McKay, J., Marshall, P., Lee, J., Viehland, D., (2008), Electronic Commerce: A Managerial Perspective, Pearson Education, International Edition, New Jersey, p. 4

Statute (EU) 2016/679 of European Parliament and Council dated April 27, 2016. on protection of individuals regarding processing personal data and free movement of such data, as well as placing out of effect of Directive 95/46/EZ, OJ L 119, 4.5.2016, p. $1-88$

Vujović, S. (2005) Electronic operations and electronic inteligence, Belgrade business school, Belgrade.

Raičević, V.,Matijašević-Obradović, J.,Kovačević, M.(2014) , Legal and ethical aspects of doing business via Internet, Synthesis 2014, p. 94-100. (95)

Raičević, V., Glomazić, Jelena Matijašević, R. (2012), Project management through IT communications, Collection of papers from I international scientific conference, ,, Power of communication 2012 “, organized on July, 1-2. Belgrade: Pan European University „Apeiron“, Banja Luka, p. 206-217 (95)

Vukmirović, G., Stojković, D., (2011), Strategy and implementationof electronic trade regarding increase of the competitiveness of Serbian economy, Faculty of economics Subotica, Subotica, p.6.

Wigand, R., (1997), Electronic Commerce: Definition, Theory and Context, School of Information studies, Syracuse University, New York, USA, str. 1.

Wolfinbarger P., Gilly Marry C. (2003), eTailQ: dimensioning, measuring and predict retail quality, Journal of Retailing, Vol.79 Issue 3, pp. 183-198.

Yoo B., Donthu N., (2001), Developing a Scale to Measure the Perceived Quality of An Internet Shopping Site (SITEQUAL), Quarterly Journal of Electronic Commerce, Vol.2 No.1, pp31-47

Law on electronic signature, National magazine no. 10/2002 
Law on electronic trade, National magazine no. 173/2003

Law on electronic document, National magazine no. 150/2005

Law on information safety, National magazine no. 79/2007

Law on electronic signature, Official gazette of BiH, no. 91/2006

Law on electronic legal and business transactions, Official gazette of $\mathrm{BiH}$, no. $88 / 2007$;

Law on electronic operations and electronic signature Official gazette of Republic of Srpska, no. 36/02.

Law on electronic operations and electronic signature (ZEPEP), Official gazette of RS, no. 57/2000 dated on 23. 6. 2000.

Law on electronic operations on the market (ZEPT), Official gazette of $R S$, no. 82/2006 dated on 30. 5. 2006.

Law on electronic trade, Official gazette of RS, no. 41/2009 and 95/2013

Law on electronic trade, Official gazette of $R C G$, no. 80/04.

Law on electronic document, Official gazette of $R C G$, no. 5/08.

Law on electronic signature, Official gazette of BiH, no. 91/06.

Law on electronic signature, Official gazette of RS no. 135/2004

Law on electronic document, Official gazette of $R S$, no. 51/2009.

Law on electronic signature, Official gazette of RCG, no. 55/03 and 31/05.

Law on electronic legal and business transaction, Official gazette of BiH, no. 88/07.

Law on information safety, „Official gazette of $R S$ “, no. 6/2016

Law on trade, Official gazette of RS, no. 53/2010 and 10/2013.

Law on personal data protection, "Official gazette of RS", no. 97/2008, 104/2009 other law, 68/2012 - decision of US and 107/2012.

Zubović, J., Domazet, I., Bradić-Martinović, A. (2011), Educational and Training Model for Implementation of E-CRM Strategy, Monograph Serbia and the European Union: Economic Lessons from the New Member States, redacted by: M.Radović Marković, S.Redžepagić, J.S.Andrade, P.Teixeira, Faculdade de Economia Universidade de Coimbra p. 359-381

Galatenko V.A. (2006), Basisi of information safety: lessons: manual, $3^{\text {rd }}$ edition. Edited by academic RAN V.B. Betelina. - M.:INTUIT.RU "Internet-university of information technologies".

Law for altering data in electronic form and electronic signature, Official gazette of Republic of Macedonia, no. 43/2001. 